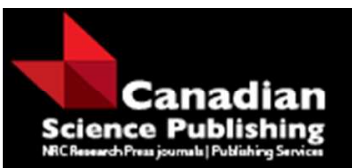

Canadian Journal of Forest Research

Revue canadienne de recherche forestière

\title{
Modeling the impacts of hemlock woolly adelgid infestation and presalvage harvesting on carbon stocks in northern hemlock forests
}

\begin{tabular}{|r|l|}
\hline Journal: & Canadian Journal of Forest Research \\
\hline Manuscript ID & cjfr-2016-0291.R2 \\
\hline Manuscript Type: & Article \\
\hline Date Submitted by the Author: & 15 -Dec-2016 \\
\hline Complete List of Authors: & $\begin{array}{l}\text { Krebs, Jeffrey; UVM, RSENR } \\
\text { Pontius, Jennifer; USDA Forest Service, Northern Research Station; UVM , } \\
\text { RSENR } \\
\text { Schaberg, Paul; USDA Forest Service }\end{array}$ \\
\hline Keyword: & $\begin{array}{l}\text { Adelges tsugae, carbon sequestration, forest vegetation simulator, FVS, } \\
\text { Tsuga canadensis }\end{array}$ \\
\hline
\end{tabular}

\section{SCHOLARONE \\ Manuscripts}




\title{
Modeling the impacts of hemlock woolly adelgid infestation and presalvage harvesting on carbon stocks in northern hemlock forests
}

\author{
Jeffrey Krebs
}

Rubenstein School of Environment and Natural Resources, University of Vermont.

Aiken Center, 81 Carrigan Drive, Burlington, VT 05405

¡krebs73@gmail.com

Jennifer Pontius (corresponding author)

Rubenstein School of Environment and Natural Resources, University of Vermont and USDA

Forest Service, Northern Research Station,

Aiken Center, 81 Carrigan Drive, Burlington, VT 05405

Jennifer.pontius@uvm.edu 802 324-9041 (cell), 802 656-3091 (work)

Paul G. Schaberg

USDA Forest Service, Northern Research Station,

Aiken Center, 81 Carrigan Drive, Burlington, VT 05405

pschaberg@fs.fed.us 
Abstract: To better understand the potential impact of HWA and presalvage activities on carbon (C) dynamics in northern hemlock stands, we used the Forest Vegetation Simulator and Forest Inventory Analysis data to model C storage and successional pathways under four scenarios: presalvage harvesting; HWA-induced mortality; presalvage harvesting plus HWA-induced mortality, and a no disturbance control. Our simulation showed that all treatments differed in total $\mathrm{C}$ storage in the short term, with HWA-induced mortality providing the highest total C storage due to regeneration and ingrowth of replacement species combined with retention of standing and downed dead wood. At the end of the 150-year simulation, all disturbance scenarios had significantly lower total $\mathrm{C}$ than the control. The cumulative net $\mathrm{C}$ gain, was lower for the two presalvage than HWA scenario, indicating that allowing HWA to progress naturally through a stand may result in the least impact to long-term $\mathrm{C}$ sequestration and net $\mathrm{C}$ storage. While differences were not significant on low hemlock density stands, impacts to the estimated 267,000 hectares of northeastern forests where hemlock is dominant could result in conversion to red maple and a net loss of over 4 million metric tons of potentially sequestered $\mathrm{C}$ over the next 150 years.

Key words: Adelges tsugae; carbon sequestration; forest vegetation simulator; FVS; Tsuga canadensis. 


\section{Introduction}

Forested ecosystems are the largest terrestrial sink that sequesters and stores atmospheric $\mathrm{CO}_{2}$, and thus play a prominent role in mitigating greenhouse gas emissions (Brown 2002; Davis et al. 2003). In the United States (U.S.) alone, it is estimated that forests store 71,000 Mt of carbon (C), and sequester an average of $155 \mathrm{Mt} \mathrm{C}$ per year. In the U.S., the Northeast averaged the highest rate of sequestration at $47 \mathrm{Mt}$ C per year (Heath et al. 2003). As a species, eastern hemlock (Tsuga canadensis (L.) Carr.) plays an important role in forest $\mathrm{C}$ dynamics because of its ability, unlike many co-occurring species, to store a substantial amount of $\mathrm{C}$ in biomass, leaf litter, and associated soils for long periods of time (Finzi et al. 1998). Compared to neighboring deciduous stands, hemlock yields higher net ecosystem production and annual C storage due to continued sequestration in early spring and late fall, and virtually no net $\mathrm{C}$ emissions in the winter months (Bardford et al. 2001; Hadley and Schedlbauer 2003; Hadley et al. 2008). The combination of these traits enable hemlock stands to both sequester and store more $\mathrm{C}$ on average than stands dominated by other common species (Hadley and Schedlbauer 2003; Hadley et al. 2008).

Since the 1980's the invasive hemlock woolly adelgid (HWA, Adelges tsugae Annand) has spread from the southern Appalachians through southern New England, causing widespread hemlock mortality that has impacted $\mathrm{C}$ fluxes by altering stand age, litter composition, species composition, nutrient cycling, and coarse woody debris levels (Orwig and Foster 1998; Stadler et al. 2005; Nuckolls et al. 2009; Albani et al. 2010). Pre-emptive cuts or salvage harvests after hemlock mortality have become common management tools in many hemlock stands (Kizlinski et al. 2002; Foster and Orwig 2006; Albani et al. 2010). These harvests are thought to encourage rapid regeneration and the establishment of early successional replacement species through soil 
scarification and increased light availability. However, it is unclear if such activities offset C lost by the removal of hemlock.

When we consider the role that hemlock plays in $\mathrm{C}$ storage and sequestration, it is critical that we understand how invasive species like HWA will affect $\mathrm{C}$ storage capacity and how presalvage and salvage operations function to alter $\mathrm{C}$ stocks over the long term (Davis et al. 2003). Studies in currently infested southern New England suggest that rapid regrowth of black birch (Betula lenta L.) will be sufficient to offset the loss of hemlock, so that stands once affected by HWA will remain a sink for atmospheric $\mathrm{CO}_{2}$ (Raymer et al. 2013; Finzi et al. 2014). However, northern hemlock stands are unlikely to respond in a similar fashion due to the extreme scarcity of black birch. In addition, these studies failed to consider the long-term impacts of continued succession beyond black birch, the differential impact of HWA-induced hemlock mortality, or how increasingly common presalvage logging practices (Foster and Orwig 2006) could influence $C$ sequestration in hemlock stands.

The goal of this research was to determine how the potential invasion of HWA and associated pre-emptive cutting and salvage harvests could affect $\mathrm{C}$ storage of hemlock stands in northern New England and New York. By using initial C pool measurements from the U.S. Forest Service Forest Inventory and Analysis (FIA) database and the Forest Vegetation Simulator tool (FVS, Crookston and Dixon 2005), our goal was to model forest C storage over the next 150 years across northern New England and New York for four HWA scenarios:

1) No disturbance (control)

2) HWA-induced hemlock mortality

3) Presalvage logging of all mature hemlock

4) Presalvage logging of all mature hemlock plus HWA infestation 
To understand how HWA will impact $\mathrm{C}$ sequestration and storage in hemlock stands is becoming increasingly important as we consider their role in mitigating $\mathrm{C}$ emissions. Further, the ability to compare HWA infestation impacts versus presalvage logging activities is critical to inform management decisions across northern hemlock forests as the infestation front continues to spread.

\section{Methods}

\section{Data collection}

The study area (Fig. 1) was limited to northern New England and New York defined by latitudes between $43^{\circ}$ and $47^{\circ} 28^{\prime} \mathrm{N}$ in order to better understand hemlock stand dynamics at the less studied northern limits of its U.S. geographic range. While hemlock is still a dominant component of mixed northern forests, it has yet to be included in research of potential HWA impacts, primarily because current HWA infestation there has been limited.

We downloaded Forest Inventory Analysis data from the FIA DataMart for the states of Maine, New Hampshire, New York, and Vermont for all FIA designated eastern hemlock plots. We used additional criteria to minimize differential impacts of land use history and maximize representation of typical mature hemlock stands in the region. These criteria limited selection to only plots with completed inventories between 2009 and 2011, a stand age greater than 70 years, site productivity between 1 and 3, slope less than $45^{\circ}$ and elevations below 2,000 feet. This allowed us to eliminate potential outlier hemlock stands that did not reflect the species' typical landscape and ecological niche, and better focus results on the applicable sites and conditions across the northern hemlock range. Hemlock stand density was classified into low $(<33 \%)$, medium (34\%-66\%) and high (>66\%) based on percent hemlock basal area (Table 1). This 
resulted in 78 hemlock-designated plots across northern New York and New England, covering a range of hemlock densities and stand composition.

We converted FIA inventory data to FVS format using the FIA2FVS program (Crookston and Dixon 2005) and 2010 was used as the initial common start year based on the timing of FIA inventory data. Stand characteristics data included geographic location, stand age, aspect, slope, elevation, forest type, and year inventoried. Individual tree data imported into FVS included species, diameter at breast height $(\mathrm{DBH})$ and tree height.

\section{Carbon simulation models}

\section{FVS initialization}

In order to understand how stand structure and $\mathrm{C}$ storage may change as HWA moves into northern New York and New England, and how much variability there is in that response, stand development and $\mathrm{C}$ pools were independently simulated for each of the 78 FIA hemlock plots over a 150-year span (2015-2165). Using the FVS model, we modeled C pools for the following scenarios: No Disturbance (control), HWA Infestation, Presalvage Harvesting with no HWA infestation post-harvest (-HWA) and Presalvage Harvesting with HWA infestation post-harvest (+HWA). These scenarios were chosen to represent a baseline of $\mathrm{C}$ sequestration and storage absent disturbance, as well as scenarios to understand the unique and combined impacts of presalvage logging and HWA infestation on long-term $\mathrm{C}$ dynamics.

The FVS Northeast variant was selected to calibrate the simulation with parameters specific to this region because it has proven applicable for modeling both even and uneven aged stands for a wide range of C assessments (Nunnery and Keeton 2010; Gunn 2014; Mika and Keeton 2014; Russell-Roy et al. 2014). Using estimates for individual tree growth and mortality, FVS mimics 
natural stand development, including succession, regeneration, and C dynamics. We used FVS regional equations to quantify $\mathrm{C}$ storage at five-year increments from 2015-2165 for seven C pools: total, Above Ground Live (AGL), Below Ground Live (BGL), Below Ground Dead (BGD), Standing Dead (SD), Down Dead Wood (DDW), and Forest Floor (FF). To better isolate the impact of HWA and presalvage treatments, settings for the FVS model also assumed the following: 1) no major disturbance other than the HWA infestation and harvest scenarios, 2) a constant climate, and 3) stable soil storage during the simulation run (Nunnery and Keeton 2010).

\section{FVS regeneration and ingrowth}

Although sprouting of certain species occurs automatically in the FVS model, users are responsible for providing estimates of natural seed-based regeneration. Following methods proposed by Arseneault et al. (2008) to integrate existing regeneration data with FVS, we built a regeneration submodel that estimates seedling regeneration based on region-specific datasets for similar site, stand and disturbance characteristics (Leak and Solomon 1975; Brooks 2004).

Regeneration inputs take into consideration species composition, shade tolerance as well as the light conditions created by the type and intensity of disturbance to estimate expected regeneration for each of the three primary disturbance scenarios (Table 2). Regeneration values from the two sources were averaged and modified to fit a 10-year span to match the regeneration cycle in FVS. Regeneration values for the presalvage (+HWA) scenario were averaged between the HWA and presalvage values. Resulting regeneration input values are similar to those used in other FVS regeneration submodels developed and applied across the region (Mika and Keeton 2015; Nunery and Keeton 2010; Russell-Roy et al. 2014). This regeneration submodel was 
initiated in 2030 and estimates regeneration on a 10-year cycle until the end of the simulation. Because FVS has been shown to be sensitive to small changes in regeneration inputs (Hoover and Rebain 2011; Ray et al. 2009) all model outputs were carefully checked to confirm that predicted growth rates were within published ranges for northern mixed hardwood forests (Leak et al. 1987; Leak and Gove 2008).

\section{FVS HWA event monitor}

While these growth and regeneration parameters served as the baseline for the four scenarios tested, we used the Hemlock Woolly Adelgid Event Monitor (Northeast variant) to adjust parameters to simulate HWA infestation (FHTET 2008). For this, a projected infestation date was established using stand-based knowledge and published projections of HWA spread. We selected 2025 as the initial infestation date based on the predicted rate of spread to the northeastern region considering current rates of spread and changing climate characteristics (Albani et al. 2010). This initialization date also permitted a baseline of $\mathrm{C}$ storage to be apparent before treatment impacts set in.

Within the Event Monitor, once infestation is initiated, HWA-induced mortality is a function of the initial infestation level and successive HWA population cycles. We used outbreak intensity and stochastic population cycles of HWA based on the empirical research of McClure (1991), where HWA populations cycle between low and high infestation densities in response to the typical decline/recovery cycle that precedes hemlock mortality in northern Appalachian stands (FHTET 2008). It includes dynamic probabilities for infestation density and HWA-induced hemlock mortality (Table 3) (FHTET 2008). Considering the role that low 
temperatures play in limiting hemlock populations (Paradis et al. 2008; Trotter and Shields 2009; Eschtruth et al. 2013), relative impacts are also modified by latitudinal location, with southern stands experiencing greater mortality.

The resulting model provides an indication of the influence of hemlock decline and mortality on timber and habitat values. It allows the user to diminish HWA impacts through the selection of management options (e.g., thinning to reduce hemlock basal area) within FVS.. It is important to note that the tree-to-tree variation in HWA impacts that are typical within stands are not adequately modeled in FVS. Therefore, this Event Monitor is more appropriate for applications such as this where many stands are evaluated to understand relative differences among management scenarios at the stand level.

\section{FVS presalvage activities (-HWA)}

We modeled pre-emptive salvage of hemlock in FVS using the management option for mechanical thinning concurrent with the initial HWA infestation date (2025). This option assumes that all hemlock trees over $25.4 \mathrm{~cm}$ DBH were cut and only merchantable hemlock biomass was removed from the site. Slash management was simulated using the basic manage logging slash function with non-merchantable material from harvested trees left on site (Dixon 2002).

\section{FVS presalvage (+HWA)}

This combined presalvage and HWA infestation scenarios. Here the prescription thinning in 2025 as described above for the pre-emptive salvage was immediately followed by the use of the 
HWA event monitor. This allowed us to simulate how infestation may progress through a thinned stand. This combined scenario may better represent effects within stands at the southern edge of the study area where infestation is likely in the near future.

\section{Data analysis}

On each of the 78 FIA inventory plots, $\mathrm{C}$ storage for total $\mathrm{C}$ (total), and six component $\mathrm{C}$ pools (AGL, SD, DDW, BGL, BGD and FF) were compared across the full simulation for the four scenarios, using a repeated measures Analysis of Variance (ANOVA). This enabled simultaneous comparison of the four scenarios, temporal trends and variability in response across stands of varying hemlock density. The net cumulative change in $\mathrm{C}$ stored, capturing $\mathrm{C}$ sequestered and stored over the full simulation, was calculated as the sum of total stand $\mathrm{C}$ change (gain or loss) from each output year over the full 150-year simulation. Results on the full data set were repeated for subsets of low- $(<33 \%$ basal area), mid- (34-66\% basal area) and highdensity (> 66\%) hemlock stands in order to understand how hemlock density impacts C storage dynamics under each scenario. Statistical results were considered significant when $P \leq 0.05$.

It is worth noting that $\mathrm{C}$ retained in wood products was not included in these calculations. While eastern hemlock is an important component of the northern forest, it is a secondary species in the regions' markets. The characteristics of hemlock wood limit its use to relatively low-grade products, such as structural lumber, pulpwood, and pallets (Howard et al. 2000). While studies (e.g. Nunery and Keeton 2010) state the importance of accounting for $\mathrm{C}$ in wood products, increased net $\mathrm{C}$ storage is primarily of importance in durable, long-lived wood products. In mixed northeastern forests, Nunery and Keeton (2010) report less than $1 \%$ of total stand C retained in wood products across a range of management intensities. Therefore, it is unlikely 
that significant deviations from these finding would occur if wood products were included in these analyses.

\section{Results and Discussion}

\section{Stand characteristics}

The 78 hemlock plots across northern New England used to initialize the FVS model averaged 95 years in age, and ranged from 70 to 215 years. Average hemlock basal area was $44 \%$ (range $5 \%$ to $88 \%$ ), with a mean of 67 metric tons $\mathrm{ha}^{-1}$ total $\mathrm{C}$ and 44 metric tons $\mathrm{ha}^{-1}$ in AGL C storage. In addition to hemlock, the most common species included red maple (Acer rubrum L.), American beech (Fagus grandifolia Ehrh.), white pine (Pinus strobus L.), sugar maple (Acer saccharum Marsh.), and yellow birch (Betula alleghaniensis Britton).

Following HWA infestation initialization, hemlock percent basal area dropped rapidly, with complete loss by the end of the 150 -year simulation (Fig. 2). In the 10 years immediately following treatment initiation, the proportion of red maple, American beech, yellow birch, and, at higher latitudes, balsam fir (Abies balsamia (L.) Mill.) initially increased, but within several decades red maple came to dominate. By the end of the simulation, species composition had stabilized to a mix of red maple, sugar maple, American beech and balsam fir, with the complete absence of hemlock. These projected shifts in species composition differ dramatically from southern studies, which in both field measurements and model simulations have consistently shown a dominance of black birch following HWA mortality (Raymer et al. 2013; Finzi et al. 2014).

Changes in species composition were similar for the presalvage treatment (Fig. 2). Because presalvage activities were set to remove only hemlock stems greater than $25.4 \mathrm{~cm}$, the overall 
initial drop in average hemlock basal area under this scenario was not extreme. Although one might surmise that, with smaller hemlock left in place, stands would eventually be dominated by residual hemlock, the simulations projected a gradual loss of hemlock and increased domination by hardwoods overtime. We propose that this transition reflected expected changes in microclimate with harvest that would then alter competitive trajectories within residual stands. The removal of large hemlock would increase light and temperature levels, and reduced moisture availability within stands. These changes would simultaneously disfavor hemlock (which thrive in the cool-moist environments that overstory hemlock create; Hadley 2000) and favor native hardwoods like red maple that compete well in the comparatively warmer and drier, moderate to high light conditions following harvest (Burns and Honkala 1990). The result of these influences would be the continued loss of hemlock basal area over time, even in the absence of HWA infestation. Nonetheless, hemlock did remain a minor component of stands for the full 150-year simulation in the absence of HWA.

Presalvage (+HWA) species composition changes were predominantly characterized by a more rapid, and near complete loss of hemlock. Within 50 years of the HWA infestation simulation, all but a handful of hemlock remained across the 78 plots. This combined presalvage (+HWA) scenario also reported the most rapid rise of red maple to dominance, peaking at just under $25 \%$ in 2065 . Sugar maple was also less competitive under this combined scenario, and was outcompeted by both American beech and balsam fir (Fig. 2)

\section{Scenario differences in total $\mathrm{C}$ and component $\mathrm{C}$ pools}

Figure 3 depicts differences in total $\mathrm{C}$ and Figure 4 the six component $\mathrm{C}$ pools for the four treatment scenarios. Over the full 150-year simulation, total stand C increased significantly for 
all treatments, but was maximized for control stands with high hemlock density (130.7 metric tons $\left.\mathrm{C} \mathrm{ha}^{-1}\right)$. By the end of the simulation, mean total stand $\mathrm{C}$ was significantly higher $(P<0.01)$ for the control (123 metric tons $\mathrm{C} \mathrm{ha}^{-1}$ ) than in either the presalvage (110 metric tons $\mathrm{C} \mathrm{ha}^{-1}$ ), HWA (108 metric tons $\left.\mathrm{C} \mathrm{ha}^{-1}\right)$ or presalvage (+HWA) (109 metric tons $\left.\mathrm{C} \mathrm{ha}^{-1}\right)$ treatments, which were statistically indistinguishable (Fig. 3).

A more detailed examination of $\mathrm{C}$ storage throughout the course of the simulation revealed how the impact of either HWA-induced mortality or presalvage treatment varied depending on the duration of the simulation (Fig. 3). For the first 20 years following simulated infestation, HWA treatments had higher total stand C stocks than both control and presalvage treatments. This was likely the result of ingrowth and regeneration in the understory that follows HWAinduced canopy thinning and increased light availability. The C in the DDW and SD pools (Fig. 4) acted to buffer the loss of live hemlock biomass while regeneration took hold. It wasn't until 30 years after the initial infestation that HWA-induced mortality and natural thinning depressed total C significantly below the control.

Similar short-term results were reported by Raymer et al. (2013) in a field trial comparing the C stocks of undisturbed primary hemlock with girdled, HWA-infested and post-HWA birch stands in southern New England. They found that ecosystem C storage was resilient to the loss of hemlock following HWA infestation, with minimal differences among forest types. While hemlock mortality resulted in large shifts in C pools from the AGL to the woody debris pool, the C storage of the stand overall was deemed resilient to the loss of hemlock due to vigorous regrowth of black birch and buffering by the woody debris pool.

Our simulation further demonstrated that presalvage activities significantly reduced total stand $\mathrm{C}$ in comparison to HWA infestation in the short term. This indicates that management 
activities that remove hemlock also eliminate potential storage in SD and DDW pools (Fig. 4), resulting in greater short-term $\mathrm{C}$ loss than HWA-induced mortality. The presalvage scenario regained levels similar to both HWA and control scenarios 25 years after harvesting.

It is important to note that, because the presalvage treatment removed only hemlock greater than $25.4 \mathrm{~cm} \mathrm{DBH}$ and allowed for continued growth of smaller trees over the 150-year simulation, it was projected that the total $\mathrm{C}$ storage for this treatment would be an overestimate of how $\mathrm{C}$ would respond in a stand that simultaneously experienced HWA-induced mortality of the remaining hemlock stock. To provide a more realistic scenario, we also conducted a Presalvage (+HWA) treatment, where total stand C was significantly lower than all other treatments in both the short and long-term. C stocks similar to those observed for the HWA and Presalvage treatments was not noted until 2110, almost 100 years after treatment initialization. This indicated that the actual impact of presalvage activities in stands imminently threatened by HWA significantly reduced stand C uptake and storage over letting HWA progress naturally through a stand in both the short and long term. Nonetheless, even in harvested stands that may not experience HWA-induced mortality, hemlocks gradually fade from prominence (Fig. 4). So whether lost through delayed HWA-induced attrition or slowly selected against through competition with hardwoods, gradual losses in hemlock post-harvest could result in similar losses in $\mathrm{C}$ sequestration potential over longer time periods.

Several other factors suggest that the loss of C from HWA infestation would not be as substantial or quick as intuitively assumed. The first is that hemlock survivorship following HWA infestation is now known to extend much longer than once thought. Eschtruth et al. (2013) noted that 10-year survivorship of hemlock in seven stands in New Jersey and adjacent Pennsylvania ranged from 70 to $94 \%$, with the 20 -year survival in some stands as high as $82 \%$. 
Furthermore, even in these mid-Atlantic forests, winter temperature lows that suppressed HWA populations were significantly associated with increased hemlock survival. Undoubtedly, the lower winter temperatures experienced in the northern forests we studied would retard HWA populations even more, thereby extending $\mathrm{C}$ sequestration of surviving hemlock.

\section{Net cumulative $\mathrm{C}$ flux}

While analyses of total $\mathrm{C}$ storage at the end of the simulation offer a useful marker to assess potential HWA impacts, the net cumulative change in $\mathrm{C}$ stored may be more meaningful. This is because it incorporates both cumulative losses from treatments and gains from regeneration and continued growth of replacement species following disturbance. As such, it represents the potential $\mathrm{C}$ sequestered and stored over time as opposed to a snapshot of storage at a given time.

The net cumulative change in $\mathrm{C}$ sequestered and stored in the short term (through year 2050) indicated that both the control and HWA treatments (both 32 net metric tons $\mathrm{C} \mathrm{ha}^{-1}$ ) were significantly higher than presalvage (29 net metric tons $\mathrm{C} \mathrm{ha}^{-1}$ ), which was in turn significantly higher than the presalvage (+HWA) scenario (24 net metric tons $\mathrm{C} \mathrm{ha}^{-1}$ ). This indicates that in the short-term, allowing HWA to play out in infested stands may be preferable to presalvage activities when maximizing short-term $\mathrm{C}$ sequestration and net $\mathrm{C}$ storage is a management objective, particularly in stands where infestation is imminent.

When our simulation was repeated with a similar end date (2100) to other HWA simulation studies (Albani et al. 2010), we still saw significant decreases in cumulative net C sequestered and stored for both HWA infestation and presalvage scenarios compared to the control. These differences between control and disturbance scenarios were maintained throughout the full 150year simulation. The control resulted in significantly higher mean net gain ( 57 net metric tons $\mathrm{C}$ 
$\mathrm{ha}^{-1}$ ) than HWA (49 net metric tons $\mathrm{C} \mathrm{ha}^{-1}$ ), which in turn was significantly higher than either presalvage or presalvage (+HWA) scenarios (both reporting net 40 metric tons $\mathrm{C} \mathrm{ha}^{-1}$ ). This represents an approximate $25 \%$ drop in potential $\mathrm{C}$ sequestration for hemlock-designated stands across the region over the next 150 years.

When breaking down these analyses by hemlock density, there were no significant differences in cumulative net $\mathrm{C}$ for low-density hemlock stands over any of the considered simulation durations. This indicates that impacts to cumulative net $\mathrm{C}$ sequestration and storage may only be a concern in stands with greater than $33 \%$ hemlock basal area. An examination of FIA basal area maps across the region shows that approximately 267,000 hectares of northern New York and New England contain greater than 33\% hemlock basal area. Therefore, across the region, the long-term impact of HWA infestation could result in a net loss of over 4 million metric tons of C sequestration and storage over the next 150 years.

These results present an interesting comparison to other studies that have modeled changes in yearly rates of net primary productivity following HWA infestation. Albani et al. (2010) predicted an initial (2020-2029) -12.8\% reduction in C uptake across the eastern U.S. due to HWA-induced mortality. However, by the end of their simulation in 2099 they projected an increase of $18.9 \%$ in yearly $\mathrm{C}$ uptake for the region as forests regenerate. They concluded that hemlock replacement species allow net productivity rates to surpass initial rates over time, negating any long-term impacts to $\mathrm{C}$ sequestration and storage. While our simulation shows similar changes in short-term productivity for disturbance scenarios, our results suggest that the cumulative impact is still a net decrease in $\mathrm{C}$ uptake and storage over both the short and longterm. 
Because $\mathrm{C}$ storage and sequestration are key metrics for access to $\mathrm{C}$ markets and important parameters when quantifying the contribution of forests to mitigate global warming (Harmon and Franklin 1990; Luyssaert et al. 2008), understanding these cumulative impacts of HWA and presalvage activities over time is critical. Our results indicate that while post disturbance regeneration may provide a boost to yearly rates of net productivity, long-term there is still a cumulative decrease in cumulative net $\mathrm{C}$ sequestration and storage that is likely to result from HWA infestation and associated presalvage harvests with a potential legacy that persists at least 150 years post disturbance.

\section{Management implications}

Although eastern hemlock is a lumber species with the potential to store $\mathrm{C}$ for extended periods, it is also commonly used in pulp and paper production (Burns and Honkala 1990), which produce products that typically sequester $\mathrm{C}$ for shorter durations. Our scenarios focused on $\mathrm{C}$ sequestration and storage within retained forests and did not consider the nature and timing of $\mathrm{C}$ released from harvested products. If land managers require short-term revenue, presalvage harvesting could be justified in northeastern hemlock forests if on-site $\mathrm{C}$ sequestration and storage were not priority objectives. Our results indicate that, while presalvage impacts on total stand C storage mirror those resulting from HWA infestation within 25-35 years of infestation, the HWA infestation scenario resulted in a significantly higher potential net gain of $\mathrm{C}$ through ongoing sequestration and storage over time. Therefore, if near-term $\mathrm{C}$ storage and sequestration within stands are management goals, our results suggest that allowing HWA to take its course may be the best alternative. While many land managers focus on the potentially catastrophic loss 
of live hemlock in HWA-impacted stands, our results indicate that C storage in other pools make up for losses in C stocks following infestation. Raymer et al. (2013) also found that this transition from living to dead $\mathrm{C}$ pools, along with new stem regeneration, mitigated the overall impact on C stocks in stands infested by HWA.

While our results suggest that $\mathrm{C}$ continues to accrue in northern hemlock forests following HWA infestation, the loss of a keystone species in the region is likely to have other ecological consequences. The unique niche that hemlock fill and the ecosystem services they support, (e.g., critical wildlife habitat, soil stabilization and water filtration along riparian buffers; Orwig et al. 2013), provide additional reasons for minimizing presalvage activities that could speed the loss of hemlock from the region's forests. This is of particular importance due to projected replacement of hemlock by functionally distinct red maple and American beech. Our results suggest that allowing HWA to progress naturally, as opposed to presalvage harvesting, will maximize on-site $\mathrm{C}$ sequestration and storage over the long-term. This is a similar conclusion reached by other studies that note the many ecological benefits derived from leaving forests alone when they are threatened by pest and pathogen outbreaks (e.g., Foster and Orwig 2006). This could also help maintain genetic pools within local hemlock populations, thereby increasing the chance that HWA-tolerant trees will survive, regenerate and spread (Foster and Orwig 2006).

\section{Conclusions}

The threat of invasive species such as HWA should always be considered when developing short- and long-term management goals. Our results indicate that both HWA infestation and presalvage logging will likely result in an increased dominance of red maple across the region, with significant and long-lived impacts on total $\mathrm{C}$ storage and sequestration across mid-high 
density northeastern hemlock forests. While many land managers have opted to conduct presalvage harvests in stands threatened by HWA, our results suggest that allowing the insect to progress naturally may have lower impacts on long-term net $\mathrm{C}$ flux than conducting presalvage harvests over the next 50 years. Considering the low market value of hemlock and the potential for incorporating $\mathrm{C}$ markets into revenue streams, this approach could become more appealing to land managers as HWA progresses northward.

It is possible that actual differences between HWA, presalvage and presalvage (+HWA) treatments could be even greater than shown by our simulation. In part, this could result from the potential overestimation of hemlock mortality rates that were based on rates of decline in southern New England. In northern hemlock forests, extreme winter temperatures are likely to curtail HWA population densities and their subsequent impacts to hemlock, resulting in slower mortality rates and a more gradual transition to replacement species (Paradis 2008). Field verification of simulation results are needed to test, and potentially to improve, the accuracy of projections for the northeastern region.

We propose that the simulation results presented here provide conservative, quantitative guidance regarding the influence of HWA infestation and salvage cutting on stand-level C sequestration and storage over time. While our results suggest that $\mathrm{C}$ continues to accrue in northern hemlock forests following HWA infestation, long-term there is still a decrease in C sequestration and the resulting cumulative net $\mathrm{C}$ storage that is likely to result from HWA infestation and associated presalvage harvests, with a potential legacy that persists at least 150 years post disturbance. 


\section{Acknowledgements}

We are grateful to Emily Russell-Roy and the staff at the Forest Vegetation Simulator Help Desk for providing technical assistance. Thanks are also extended to Drs. Timothy Perkins, Emily Russell-Roy and George Allez for input on an earlier version of this manuscript. This research was supported in part by the USDA Forest Service Northern Research Station. 


\section{References}

Albani, M., Moorcroft, P.R., Ellison, A.M., Orwig, D.A., and Foster, D.R. 2010. Predicting the impact of hemlock woolly adelgid on carbon dynamics of eastern United States forests. Can. J. For. Res. 40: 119-133.

Arseneault, J.E., Kershaw, J.A., McCarter, J.B., and Maclean, D.A. 2008. Forest vegetation simulator ingrowth tool: Incorporating ingrowth tree lists into forest vegetation simulator growth projections. North. J. Appl. For. 25: 158-160.

Barford, C.C., Wofsy, S.C., Goulden, M.L., Munger, J.W., Pyle, E.H., Urbanski, S.P., Hutyra, L., Saleska, S.R., Fitzjarrald, D., and Moore, K. 2001. Factors controlling long- and short-term sequestration of atmospheric $\mathrm{CO}_{2}$ in a mid-latitude forests. Science 294(5547): 1688-1691.

Brooks, R.T. 2004. Early regeneration following the presalvage cutting of hemlock from hemlock-dominated stands. North. J. Appl. For. 21: 12-18.

Brown, S. 2002. Measuring carbon in forests: current status and future challenges. Environ. Pollut. 116: 363-372.

Burns, R., and Honkala, B. 1990. Silvics of North America: 1. Conifers; 2. Hardwoods Agriculture Handbook 654. US Department of Agriculture, Forest Service, Washington, DC.

Crookston, N. L., and Dixon, G.E. 2005. The forest vegetation simulator: a review of its structure, content, and applications. Compute. Electron. Ag. 49: 60-80.

Davis, M.R., Allen, R.B., and Clinton, P.W. 2003. Carbon storage along a stand development sequence in a New Zealand Nothofagus forest. For. Ecol. Manage. 177: 313-321. 
Dixon, G.E. 2002. Essential FVS: A user's guide to the Forest Vegetation Simulator. U. S. Department of Agriculture, Forest Service, Forest Management Service Center. Fort Collins, CO, USA.

Eschtruth, A.K., Evans, R.A., and Battles, J.J. 2013. Patterns and predictors of survival un Tsuga Canadensis populations infested by the exotic pest Adelges tsugae: 20 years of monitoring. For. Ecol. Manage. 305: 195-203.

Finzi, A.C., Van Breemen, N., and Canham, C.D. 1998. Canopy tree-soil interactions within temperate forests: species effects on soil carbon and nitrogen. Ecol. Appl. 8(2): 440-446.

Finzi, A.C., Raymer, P.C., Giasson, M.A., and Orwig, D.A. 2014. Net primary production and soil respiration in New England hemlock forests affected by the hemlock woolly adelgid. Ecosphere 5(8): 1-16.

FHTET. 2008. The Hemlock Woolly Adelgid Event Monitor Users' Guide. United States Department of Agriculture, Forest Service, Forest Health Technology Enterprise Team. Morgantown, WV, USA.

Foster, D. R., and Orwig, D.A. 2006. Pre-emptive and salvage harvesting of New England forests: When doing nothing is a viable alternative. Conserv. Biol. 20: 959-970.

Godman, R.M., and Lancaster, K. 1990. Tsuga Canadensis (L.) Carr. Silvics of North America. Vol. 1. Conifers. USDA Forest service

Gunn, J. S., Ducey, M.J., and Whitman, A.A. 2014. Late-successional and old-growth forest carbon temporal dynamics in the northern forest: northeastern USA. For. Ecol. Manage. 312: $40-46$.

Hadley, J.L. 2000. Understory microclimate and photsynthetic response of saplings in an oldgrowth eastern hemlock (Tsuga Canadensis L.) forest. Ecoscience 1: 66-72. 
Hadley, J. L., Kuzeja, P.S., Daley, M.J., Phillips, N.G., Mulcahy, T., and Singh, S. 2008. Water use and carbon exchange of red oak- and eastern hemlock-dominated forests in the northeastern USA: implications for ecosystem-level effects of hemlock woolly adelgid. Tree Physiol. 28: 615-627.

Hadley, J.L., and Schedlbauer, J.L. 2003. Carbon exchange of an old-growth eastern hemlock: Tsuga canadensis forest in central New England. Tree Physiol. 23: 719-719.

Harmon, M.E., and Franklin, F.W. 1990. Effects on Carbon Storage of Conversion of OldGrowth Forests to Young Forests. Science 247: 699-702.

Heath, L.S., Smith, J.E., and Birdsey, R.A. 2003. Carbon Trends in U.S. Forestlands: A Context for the Role of Soils in Forest Carbon Sequestration. CRC/Lewis Publishers, Boca Raton, FL, USA.

Hoover, C.M., and Rebain, S.A. 2011. Forest carbon estimation using the Forest Vegetation Simulator: Seven things you need to know. General Technical Report NRS-77. Newtown Square, PA: U.S. Department of Agriculture, Forest Service, Northern Research Station. $16 \mathrm{p}$.

Howard, T., Sendak, P. and Codrescu, C., 2000. Eastern hemlock: a market perspective. Proceedings: Symposium on Sustainable Management of Hemlock Ecosystems in Eastern North America GTR-NE-267

Kizlinski M.L., Orwig, D.A., Cobb, R.C., and Foster, D.R. 2002. Direct and indirect ecosystem consequences of an invasive pest on forests dominated by eastern hemlock. J. Biogeog. 29: $1489-1503$. 
Leak, W.B., and Gove, J.H. 2008. Growth of northern hardwoods in New England: a 25-year update. North. J. Appl. For. 25: 103-105.

Leak, W.B., and Solomon, D.S. 1975. Influence of residual stand density on regeneration of northern hardwoods. United States Department of Agriculture, Forest Service, Northeastern Forest Experiment Station. Upper Darby, PA, USA.

Leak, W.B., Solomon, D.S., and DeBald, P.S. 1987. Silvicultural guide for northern hardwood types in the Northeast (Revised). Research Paper NE-603. Broomall, PA: U.S. Department of Agriculture, Forest Service, Northeastern Forest Experiment Station. 36 p.

Luyssaert, S.E., Borner, A., Knohl, A., Hessenmoller, D., Law, B., Ciais, P., and Grace, J. 2008. Old-growth forests as global carbon sinks. Nature 455: 213-215.

McClure, M.S. 1991. Density-dependent feedback and population cycles in Adelges tsugae: Homoptera:Adelgidae) on Tsuga canadensis. Environ. Ent. 20: 258-264.

Mika, A.M., and Keeton, W.S. 2014. Net carbon fluxes at stand and landscape scales from wood bioenergy harvests in the US Northeast. Glob. Change Biol. Bioenergy 7: 438-454.

Nuckolls, A.E., Wurzburger, N., Ford, C.R., Hendrick, R.L. Vose, J.M., and Kloeppel, B.D. 2009. Hemlock declines rapidly with hemlock woolly adelgid infestation: Impacts on the carbon cycle of southern Appalachian forests. Ecosystems 12: 179-190.

Nunnery, J.S., and Keeton, W.S. 2010. Forest carbon storage in the northeastern United States: net effects of harvesting frequency, post-harvest retention, and wood products. Ecol. Appl. 259: 1363-137.

Orwig, D. A., and Foster, D.R. 1998. Forest response to the introduced hemlock woolly adelgid in southern New England, USA. J. Torrey Bot. Soc. 125: 60-73. 
Orwig, D.A., and Barker Plotkin, A.A. 2013. Foundation species loss affects vegetation structure more than ecosystem function in a northeastern USA forest. PeerJ 1: e41-e41.

Paradis, A., Elkinton, J., Hayhoe, K., and Buonaccorsi, J. 2008. Role of winter temperature and climate change on the survival and future range expansion of the hemlock woolly adelgid: Adelges tsugae) in eastern North America. Mitigat. Adapt. Strateg. Glob. Change 13: $541-554$.

Ray, D.G., Saunders ,M.R. and Seymour, R.S. 2009. Recent changes to the northeast variant of the forest vegetation simulator and some basic strategies for improving model outputs. North. J. Appl. For. 26: 31-34.

Raymer, P.C., Orwig, D.A., and Finzi, A.C. 2013. Hemlock loss due to the hemlock woolly adelgid does not affect ecosystem C storage but alters its distribution. Ecosphere 4(5): 116.

Russell-Roy, E.T., Keeton, W.S., Pontius, J.A., and Kerchner, C.D. 2014. Rehabilitation forestry and carbon market access on high-graded northern hardwood forests. Can. J. For. Res. 44: $614-627$.

Stadler, B., Muller, T., Orwig, D., and Cobb, R. 2005. Hemlock woolly adelgid in New England forests: Canopy impacts transforming ecosystem processes and landscapes. Ecosystems 8: $233-247$.

Trotter, T.R. and Shields, K.S. 2009. Variation in winter survival of the invasive hemlock woolly adelgid (Hemiptera: Adelgidae) across the eastern United States. Environmental Entomology 38(3): 577-587. 
Table 1. The number of FIA stands by basal area and state for our simulation study. Stands were classified as High ( $>55 \%)$, Medium $(>33 \%$ to $<55 \%)$, and Low $(<33 \%)$ hemlock basal area.

\begin{tabular}{cccc}
\hline \hline & \multicolumn{3}{c}{ Hemlock density } \\
State & High & Medium & Low \\
\hline ME & 9 & 13 & 12 \\
NH & 4 & 7 & 3 \\
NY & 6 & 8 & 4 \\
VT & 5 & 5 & 2 \\
Total & 24 & 33 & 21 \\
\hline
\end{tabular}


Table 2. Ten-year regeneration seedling counts per hectare for post disturbance and ingrowth by treatment and species composition from two regional regeneration data sets (Leak and Solomon 1975; Brooks 2004).

\begin{tabular}{rcccc} 
Species & Control & HWA & Presalvage & $\begin{array}{c}\text { Presalvage } \\
(+\mathrm{HWA})\end{array}$ \\
\hline Tsuga canadensis & 116 & 0 & 0 & 0 \\
Pinus strobus & 20 & 78 & 51 & 65 \\
Acer rubrum & 1494 & 7012 & 6914 & 6963 \\
Acer saccharum & 122 & 829 & 1192 & 1011 \\
Betula alleghaniensis & 282 & 2774 & 4864 & 3819 \\
Fagus grandifolia & 961 & 5130 & 5972 & 5551 \\
Fraxinus americana & 301 & 2285 & 3536 & 2911 \\
Populus sp. & 0 & 73 & 179 & 126 \\
Quercus rubra & 40 & 134 & 51 & 93 \\
Prunus serotina & 20 & 67 & 25 & 46 \\
Prunus pennsylvanica & 73 & 410 & 504 & 457 \\
Acer pensylvanicum & 204 & 1148 & 1410 & 1279 \\
Betula papyrifera & 44 & 246 & 302 & 274 \\
Abies balsamea & 2 & 12 & 15 & 14 \\
Picea rubens & 2 & 12 & 15 & 14 \\
\hline
\end{tabular}


Table 3. Probability distributions of HWA infestation intensity (FHTET 2008, Northeast variant) and resulting hemlock mortality were assigned using an average initial HWA infestation date of 2025 .

\begin{tabular}{lcc}
\hline \hline \multicolumn{1}{c}{ HWA density } & Probability of occurrence & Resulting hemlock mortality \\
\hline No Infestation & 0 & 0 \\
Low Infestation & 0.4 & $0-5 \%$ \\
Moderate Infestation & 0.3 & $5-30 \%$ \\
High Infestation & 0.2 & $30-70 \%$ \\
Catastrophic Infestation & 0.1 & $70-90 \%$ \\
\hline
\end{tabular}




\section{Figure Captions}

Fig. 1. The northern New York and New England study area boundary includes hemlockdominated forests at latitudes between $43^{\circ} \mathrm{N}$ and $47^{\circ} 28^{\prime} \mathrm{N}$.

Fig. 2. Simulated changes in percent basal area provide an approximation of how species composition may change following HWA (top) and presalvage (bottom) treatments in northern New York and New England hemlock stands. Species codes are: TSCA (Tsuga canadensis), ACRU (Acer rubrum), BELE (Betula lenta), FAGR (Fagus grandifolia), QURU (Quercus rubra), ABBA (Abies balsamea), ACSA3 (Acer saccharum), and BEAL2 (Betula alleghaniensis).

Fig. 3. Modeled total carbon storage for HWA-induced mortality, presalvage harvest, presalvage (+HWA), and control from 2010 to 2160 , including a breakdown of total $\mathrm{C}$ by hemlock stand density (where high density $=>66 \%$ and low density $=<33 \%$ ).

Fig. 4. Dominant carbon stores under the four simulation treatments for six key carbon pools. 
Fig. 1

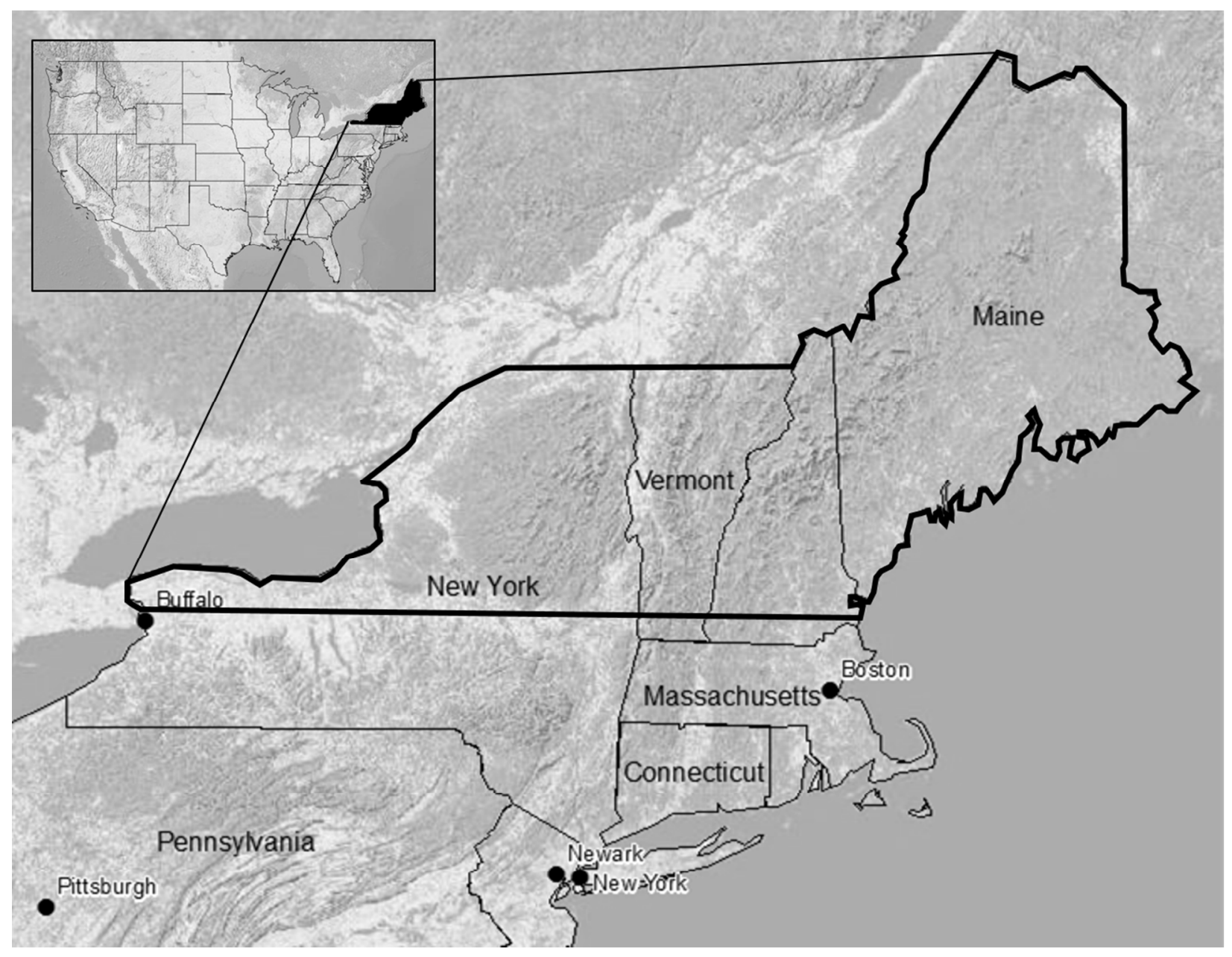


Fig. 2

\section{HWA}

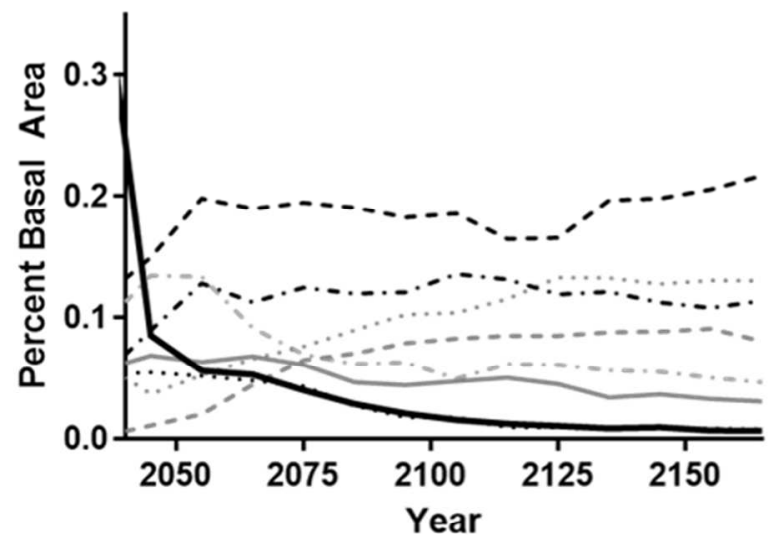

$$
\begin{array}{ll}
\text { - } & \text { TSCA } \\
\cdots & \text { ACRU } \\
\cdots & \text { BELE } \\
\cdots & \text { FAGR } \\
- & \text { QURU } \\
\cdots & \text { ABBA } \\
\cdots & \text { ACSA3 } \\
\cdots & \text { BEAL2 }
\end{array}
$$

Presalvage

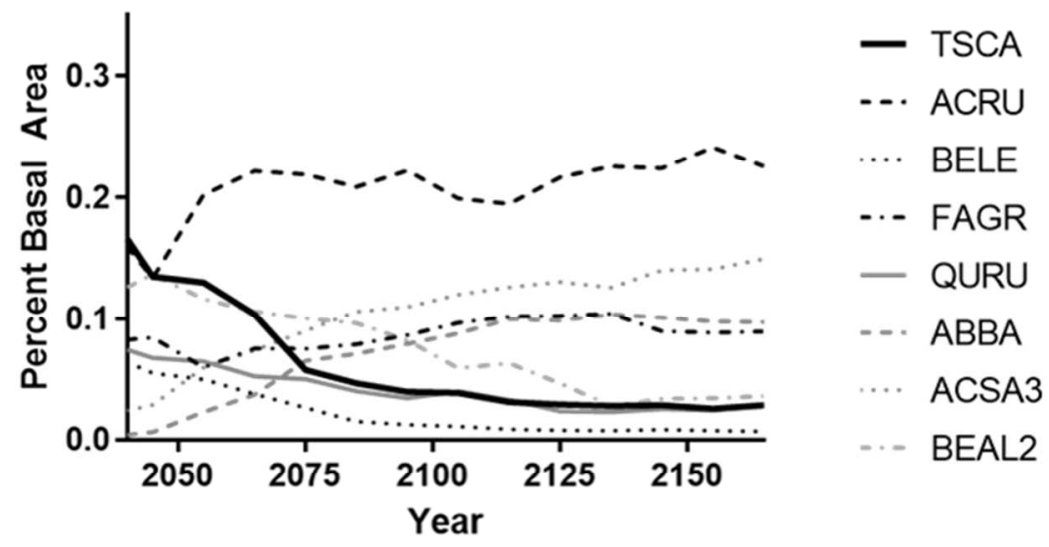

\section{Presalvage +HWA}

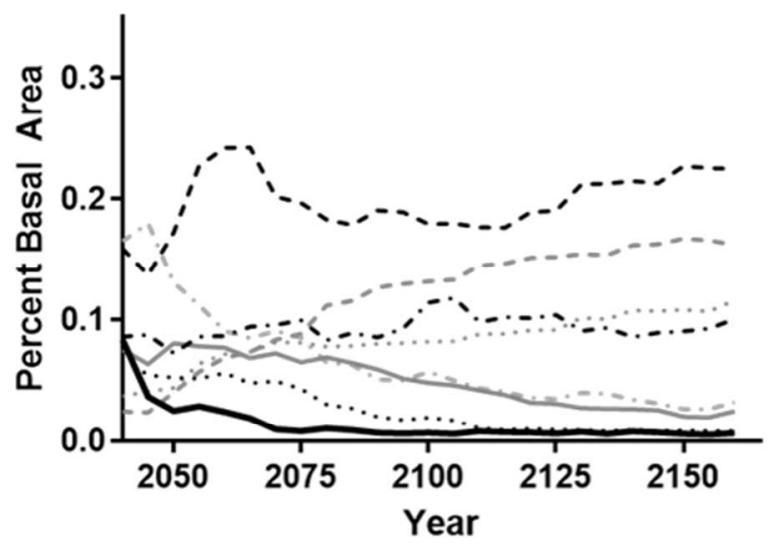

$\begin{array}{ll}\text { - } & \text { TSCA } \\ \cdots & \text { ACRU } \\ \cdots & \text { BELE } \\ \cdots & \text { FAGR } \\ - & \text { QURU } \\ \cdots & \text { ABBA } \\ \cdots & \text { ACSA3 } \\ \cdots & \text { BEAL2 }\end{array}$ 
Fig. 3
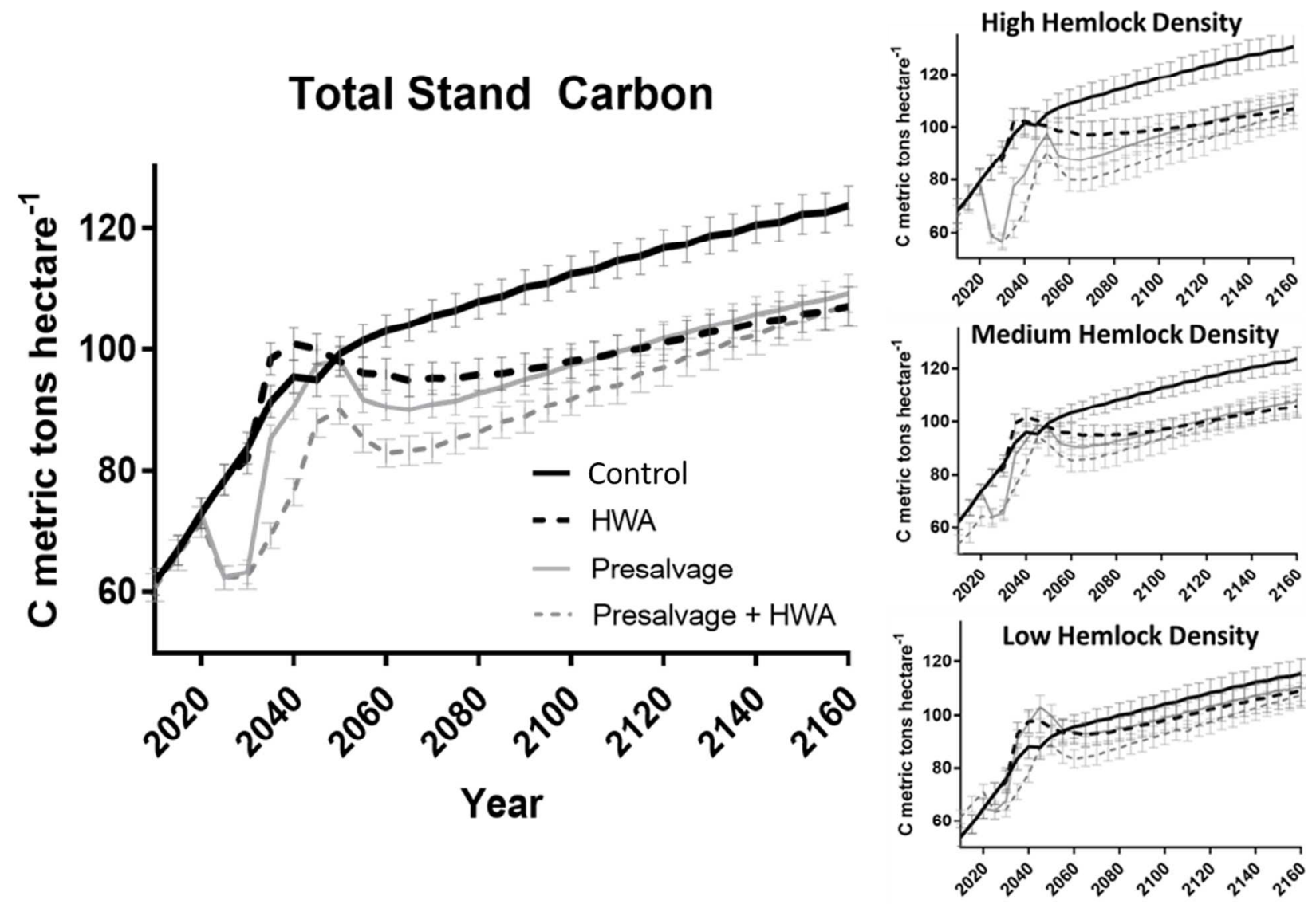
Fig. 4
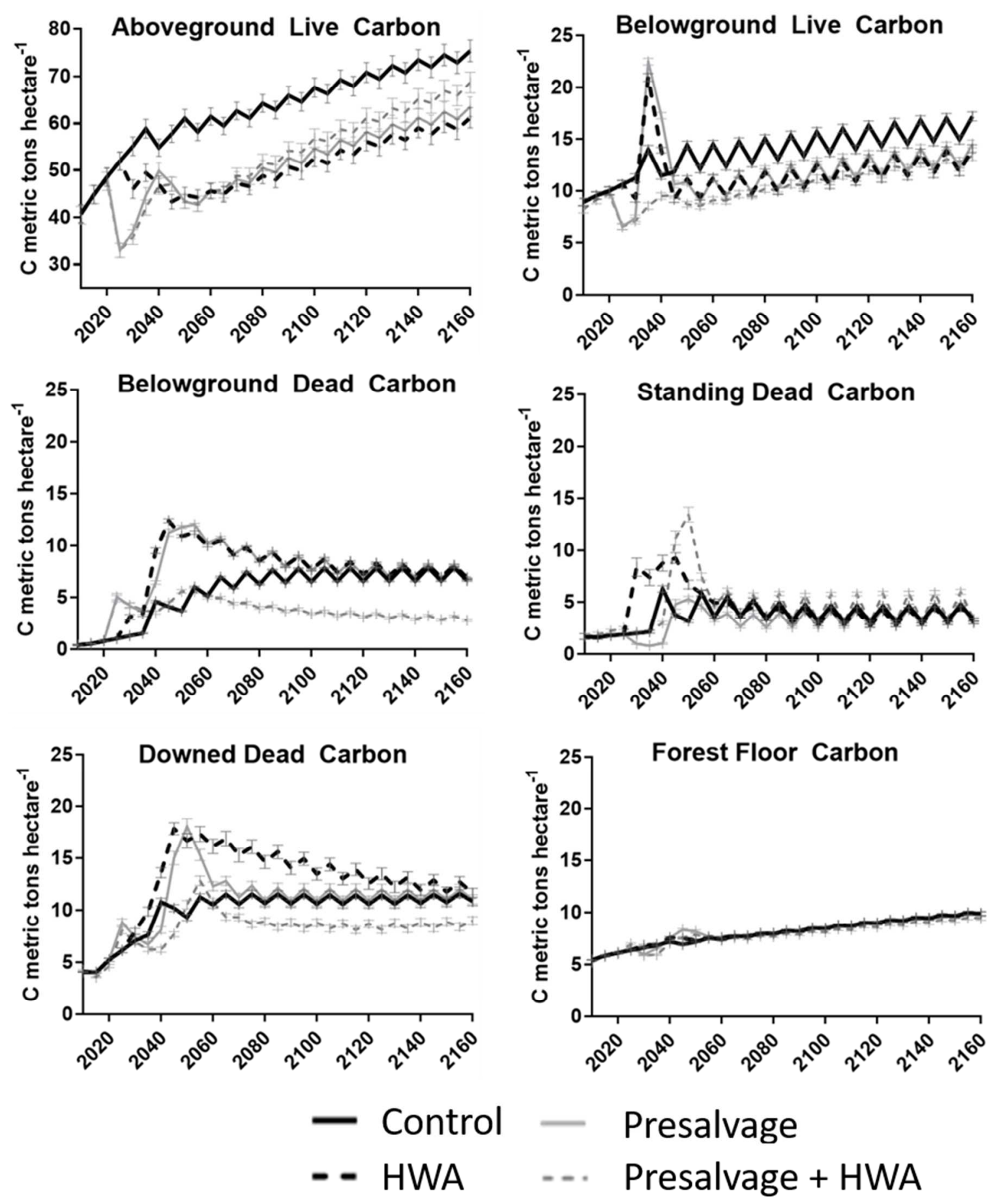